\title{
Potential impact of small hydroelectric power plants on river biota: a case study on macroinvertebrates associated to basaltic knickzones
}

\author{
A. M. C. Ruocco ${ }^{*}$, J. L. Portinho ${ }^{b}$ and M. G. Nogueira ${ }^{a}$ \\ aDepartamento de Zoologia, Universidade Estadual Paulista - UNESP, Rua Prof. Dr. Antonio Celso Wagner Zanin, s/n, \\ Distrito de Rubião Júnior, CEP 18618-689, Botucatu, SP, Brasil \\ 'Laboratório de Biologia Aquática, Departamento de Biologia, Universidade Estadual Paulista - UNESP, \\ Avenida Dom Antonio, 2100, Parque Universitário, CEP 19806-900, Assis, SP, Brasil \\ *e-mail: ana.ruocco@yahoo.com.br
}

Received: February 4, 2018 - Accepted: March 7, 2018 - Distributed: November 30, 2019

(With 6 figures)

\begin{abstract}
Small hydroelectric power plants (SHP) have been considered as an alternative for the generation of electricity with reduced environmental impacts. Nevertheless, no studies have addressed changes in a particular kind of river macrohabitat commonly affected by SHPs, the knickzones. This study aimed to assess the impact of a SHP construction on the aquatic macroinvertebrate fauna associated with two basaltic knickzones located in Sapucaí-Mirim River, Southeast Brazil. The first, considered as a functional knickzone, follows the natural dynamics of the river flow and preserves the original rock substrate. The second, considered as non-functional knickzone, was permanently flooded after the SHP construction and the consolidated rock substrate was changed by fine sediment. Sampling was carried out in two seasonal periods and the data were analysed through multivariate analysis. It was observed differences in composition and structure of the macroinvertebrates community between the knickzones and periods. The functional knickzone exhibited a much higher richness, 72 taxa compared to 44 in the non-functional, as well as a large number of exclusive taxa (38, being only nine exclusive to the non-functional). Diversity, equitability and density mean values were also higher in the functional knickzone. The limnological parameters varied significantly between dry and rainy seasons but not between the distinct knickzones. This kind of macrohabitats and its potential role for the rivers biodiversity is practically unknown. In the scenery of fast SHP expansion, further studies and protection measures are necessary.
\end{abstract}

Keywords: bedrock rivers, environmental alteration, habitat conservation, macrohabitats, Sapucaí-Mirim river.

\section{Potencial impacto de pequenas centrais hidreléticas sobre a biota aquática: um estudo de caso sobre macroinvertebrados associados a pedrais basálticos}

\begin{abstract}
Resumo
Atualmente, a instalação de pequenas centrais hidrelétricas ( $\mathrm{PCHs}$ ) tem sido a alternativa mais visada quando a questão é suprir a demanda energética, considerando-se os menores impactos ambientais possíveis. Contudo, são escassos os trabalhos que avaliam as alterações causadas por esses empreendimentos, principalmente no que se diz respeito a um tipo de macro-habitat de rios, os pedrais. Assim, este estudo teve como objetivo avaliar o impacto da construção de uma PCH na fauna de macroinvertebrados aquáticos associada a dois pedrais basálticos, localizados no rio Sapucaí-Mirim, no Sudeste do Brasil. O primeiro, considerado como um pedral funcional, segue a dinâmica natural do fluxo do rio e possui o substrato rochoso original. O segundo, considerado como pedral não funcional, foi permanentemente inundado após a construção da PCH e o substrato consolidado foi alterado por sedimentos finos. A amostragem foi realizada em dois períodos sazonais e os dados foram analisados através de análise multivariada. Foram observadas diferenças na composição e estrutura da comunidade de macroinvertebrados entre os pedrais e períodos. O pedral funcional apresentou uma riqueza muito maior, 72 táxons em comparação com 44 no não funcional, bem como um grande número de táxons exclusivos (38, sendo apenas nove exclusivos do não-funcional). Os valores médios da diversidade, equitabilidade e densidade também foram maiores no pedral funcional. Os parâmetros limnológicos variaram significativamente entre as estações seca e chuvosa, mas não entre os diferentes pedrais. Este tipo de macro-habitat e seu potencial papel para a biodiversidade dos rios são praticamente desconhecidos. Assim, mais estudos e medidas de proteção são necessários, principalmente diante do atual cenário de rápida expansão das PCHs.
\end{abstract}

Palavras-chave: rios rochosos, alterações ambientais, conservação de habitas, macro-habitas, rio Sapucaí-Mirim. 


\section{Introduction}

Human population growth, economic development, climate change and the need to address the fact that more than 1.4 million people are still disconnected from electricity supplies have boosted hydropower construction. Worldwide, approximately 8,600 dams primarily designed for hydropower generation are in operation (Zarfl et al., 2015). Currently, small hydroelectric power plants (SHPs) (production $<30 \mathrm{MW}$ ) are considered a renewable and sustainable option for providing energy (Premalatha et al., 2014; Spänhof, 2014). However, some recent studies have stressed that the impacts of this kind of power plant on river water quality and structure of biological communities (Jesus et al., 2004; Mantel et al., 2010; Premalatha et al., 2014) could be equivalent to the already widely reported effects of larger hydropower plants. Nevertheless, the impact of reservoir construction on a particular river macrohabitat, the knickzones, has not been considered.

Knickzones are shallow river stretches geologically characterized by the presence of rock outcrops (Hayakawa and Oguchi, 2006, 2009) and because of their solid consolidated substrate, these environments are propitious sites for hydroelectric dams' axis positioning. Only recently, the threat to knickzones caused by hydroelectric projects was evidenced in Brazil, during the controversial construction of the huge hydroelectric plant of Belo Monte in the Xingu River, Amazon Basin (Winemiller et al., 2016). Although the knickzones are commonly observed around the world, these environments have been largely unstudied in river ecology. Some works have analysed the spatial distribution and geological formation of fluvial knickzones (Walsh et al., 2012; Pederson and Tressler, 2012; Lima and Binda, 2013), but they did not focus on the environmental and biotic changes related to human interferences.

Brambilla et al. (2018) characterized basaltic knickzones (volcanic origin) as a complex aquatic habitat, composed of riffles, runs and pools distributed in a mosaic. They pointed the differences in depth, turbulence, velocity and flow as well as the degree of connectivity of the distinct habitats with the main river flow resulting in very high local heterogeneity in these macrohabitats. The inherent high complexity and the difficulties to access the knickzones, impossible by conventional boat for instance, can be the reason for the lack of knowledge about these environments.

Our premise is that the construction of SHPs, as the larger hydroelectric plants, alters the sediment and the natural hydrodynamic processes in knickzone areas, deeply influencing the benthic communities, such as the aquatic macroinvertebrates. This community constitutes an important link of the food chains, being fundamental for the dynamics of the aquatic ecosystems. These organisms also participate in nutrient exchanges between sediment and interfacial water, such as phosphorus and nitrogen, either through excavation / bioturbation activities or by direct action in the fragmentation / decomposition / mineralization of organic matter (Esteves, 2011). In addition, they constitute a community particularly indicative of changes in the aquatic environment (Rosenberg and Resh, 1993; Callisto et al., 2004; Esteves, 2011).

Thereby, the aim of this study was to assess the impact of SHPs on the aquatic macroinvertebrate fauna associated with basaltic knickzones, considering two distinct areas for comparison: one influenced and another not influenced by SHP construction. We postulated that the knickzone, which is directly influence by the natural flow hydrodynamic alternating periods of flood and partial exposition of the bedrock substrate, called here as functional, would show higher values of diversity, density and richness compared to the non-functional knickzone, which remains permanently flooded, undergoing deposition of fine sediment due to river regulation.

\section{Methods}

\subsection{Study area}

Two basaltic knickzones located in the Sapucaí-Mirim River, Southeast Brazil, were studied. The Sapucaí-Mirim River is located in the high Paraná Basin and it is a 5th order river, approximately $290 \mathrm{~km}$ in length, characterized by an alternating longitudinal profile between fast flow stretches and sequences of small knickpoints.

Both basaltic knickzones studied were located upstream of an SHP dam named Palmeiras, installed since July 2011 (Figure 1). The first knickzone is $7.5 \mathrm{~km}$ above the dam $\left(20^{\circ} 34^{\prime} 34.1^{\prime \prime} \mathrm{S}, 47^{\circ} 47^{\prime} 06.5^{\prime \prime} \mathrm{W}\right)$ and is not directly influenced by the reservoir tail, staying flooded or exposed according to volume and level of water flow, which are influenced by seasonal rainfall or drought as well as atypical weather events (Figure 1a, b). Therefore, it was considered as a functional knickzone $(\mathrm{F})$. The substrate of the functional knickzone is basaltic, formed by strong bed rock, basically a continuous platform, as well as smaller isolated areas with some sand accumulation.

The second knickzone is in the transitional (lotic-lentic)

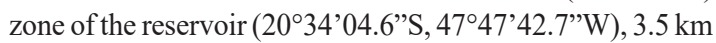
downstream the functional one, and it was considered as non-functional (NF) because of its permanently flooded condition (Figure 1a, b). The substrate is presently filled by fine sand, very fine sand, silt and clay deposited over the original consolidated bedrock.

\subsection{Sampling design}

Sampling was carried out in September 2012, late winter (dry season), and in May 2013, late summer (rainy season). During each period, twenty-four macroinvertebrate samples were collected along a transversal transect, from the left to right margin, across run areas. In the functional knickzone, samples were collected with a surber $\left(0.09 \mathrm{~m}^{2}, 250 \mu \mathrm{m}\right)$, whereas in the non-functional knickzone, samples were collected with a van Veen sampler $\left(0.0198 \mathrm{~m}^{2}\right)$. Different equipments were selected due to the local characteristics, i.e., the type of sediment and water column depth (Brandimarte et al., 2004), and the data were standardized to individuals per $\mathrm{m}^{2}$ for comparisons. 


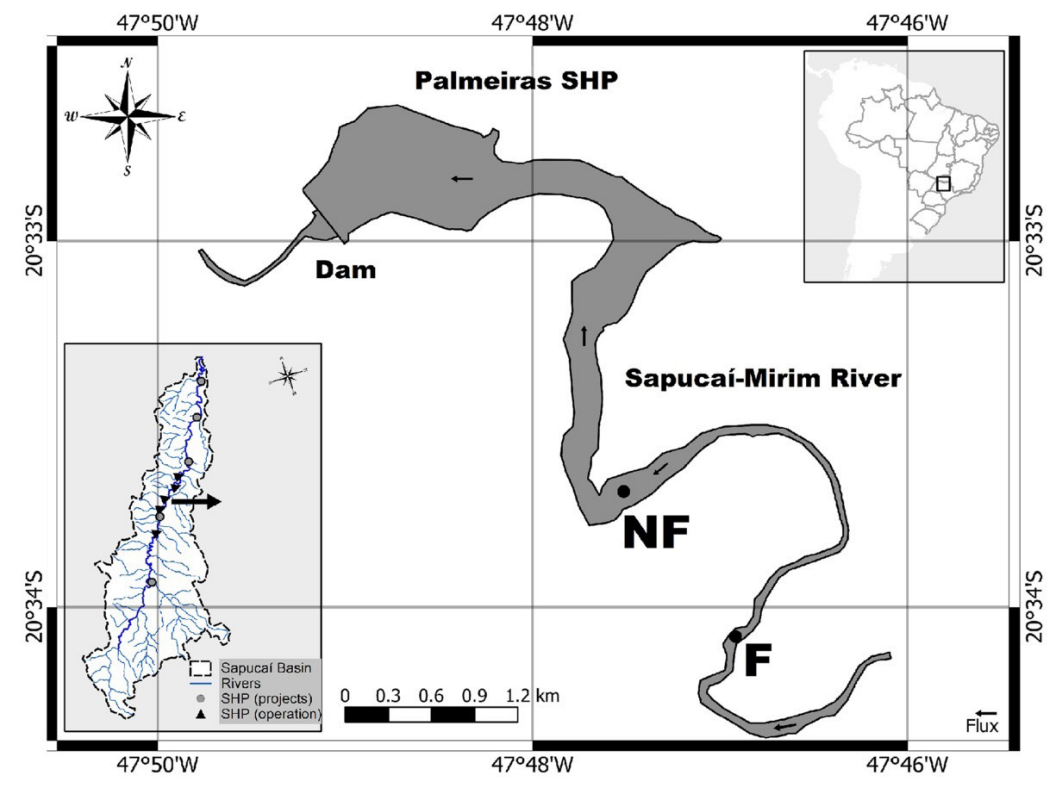

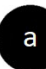

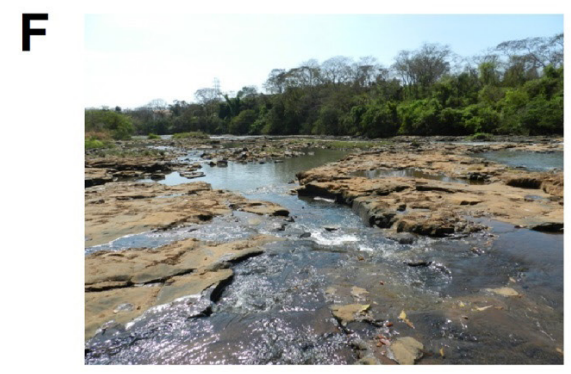

NF

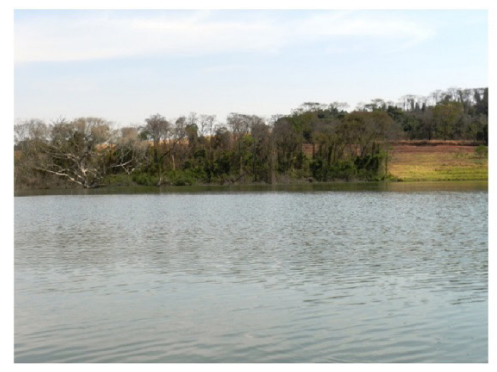

b
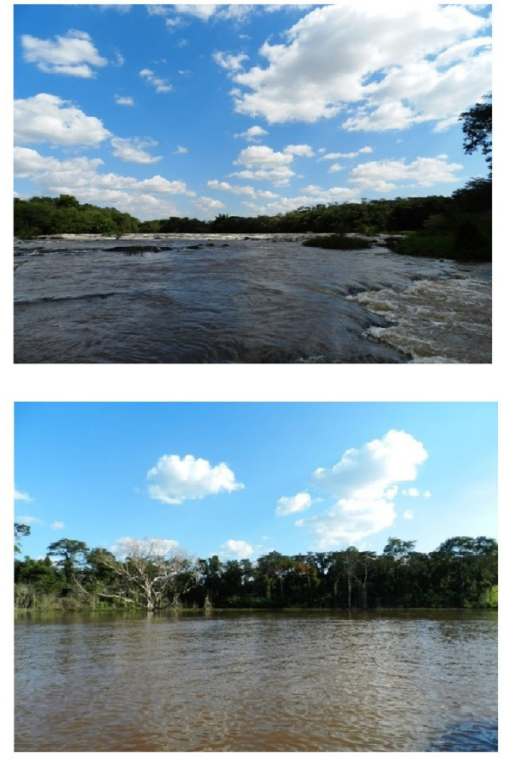

Figure 1. Map of the Palmeiras SHP showing the sampling sites. $\mathrm{F}=$ functional knickzone; NF = non-functional basaltic knickzone in late winter (a) and late summer period (b).

The samples were washed through $250-\mu$ m mesh size sieves, fixed in $4 \%$ formalin, washed in tap water and stored in $70 \%$ alcohol. The organisms were identified to the lowest taxonomic level based on specialized literature (Pennak, 1989; Brinkhurst and Marchese, 1989; Lopretto and Tell, 1995; Merritt and Cummins, 1996; Mariano and Froehlich, 2007; Domínguez and Fernández, 2009; Krantz and Walter, 2009; Mugnai et al., 2010).

Simultaneously, the following water quality parameters were measured: $\mathrm{pH}$, conductivity $(\mathrm{K})$, turbidity $(\mathrm{Tb})$, dissolved oxygen (DO), oxygen saturation percentage (\% Sat.), temperature (T), oxide reduction potential (ORP), and total dissolved solids (TDS) using a calibrated Horiba probe (U-52). Water samples were also collected for the determination of total nitrogen (TN) (Mackereth et al., 1989), total phosphorus (TP) (Strickland and Parsons, 1960), total solids (TS) (APHA, 2012), organic suspended solids (OSS), inorganic suspended solids (ISS), total suspended solids (TSS) (sensu Cole, 1979), and chlorophyll $a$ (Chl- $a$ ) (Talling and Driver, 1961). 
Depth was measured with a Speedtech ${ }^{\circledR}$ sonar or rule in each individual sampling point along the river cross-section. The rainfall data for the studied period were obtained from National Institute of Meteorology (INMET, 2014), Franca city weather station.

\subsection{Data analysis}

Two-way ANOVA followed by Tukey's test was applied for the detection of environmental differences between the functional and non-functional basaltic knickzones and seasonal periods. All data were $\log (\mathrm{x}+1)$ transformed except for $\mathrm{pH}$. A PCA was performed in PRIMER v6.0 to identify spatial and temporal patterns of variation in the environmental data (Clarke and Gorley, 2006).

The macroinvertebrate counts were converted to densities (individuals per $\mathrm{m}^{2}$ ) prior to the statistical analyses. For comparisons between both areas and both periods the following macroinvertebrates structure descriptors were used: density, relative abundance, Shannon's diversity index and Pielou's equitability (determined with PAST software, Hammer et al., 2001).

We performed two-way ANOVA followed by Tukey's test to identify significant differences in richness, density, Shannon's diversity index and Pielou's equitability (Zar, 1999) in Statistica 7.0 (StatSoft, 2004). The factors were functional and non-functional knickzones and seasonal periods.

To characterize the macroinvertebrate community structure in each basaltic knickzone, we used non-metric multidimensional scaling (NMDS) derived from Bray-Curtis similarity matrices using square-root transformed density data (Clarke and Warwick, 2001). Similarity analysis (ANOSIM) and specific composition analysis (SIMPER) were applied to the groups obtained in the NMDS analysis. ANOSIM tested the null hypothesis of no difference between the knickzones in each period, and SIMPER determined the main taxa responsible for the observed differences. Both tests were conducted using PRIMER (v6.0) (Clarke and Gorley, 2006) with the PERMANOVA+ add-on (Anderson et al., 2008).

\section{Results}

\subsection{Environmental parameters}

Daily precipitation $(\mathrm{mm})$ recorded in the month preceding each sampling date and the seasonal distribution of rains $(\mathrm{mm})$ in the studied period are presented in Figure 2. It shows that September sampling was preceded by a long dry condition $(0.0 \mathrm{~mm}$ in August), different from the considerable high precipitation immediately before and in May as well.

The mean values and standard deviations of the measured environmental parameters are shown in Table 1. All parameters were significantly different (two-way ANOVA, $p<0.05$ ) between the two periods or for the interaction of period-knickzone except for the oxygen saturation percentage and total solids. A similar trend was observed in the PCA (Figure 3), with periods being separated on the first axis ( $74.2 \%$ of variance explicability) and the non-functional knickzone in September 2012 on the second axis (15.6\% of variance explicability). In September, both knickzones showed higher values of $\mathrm{pH}$, conductivity, temperature, total dissolved solids, total solids, total nitrogen and total phosphorus. In May, both
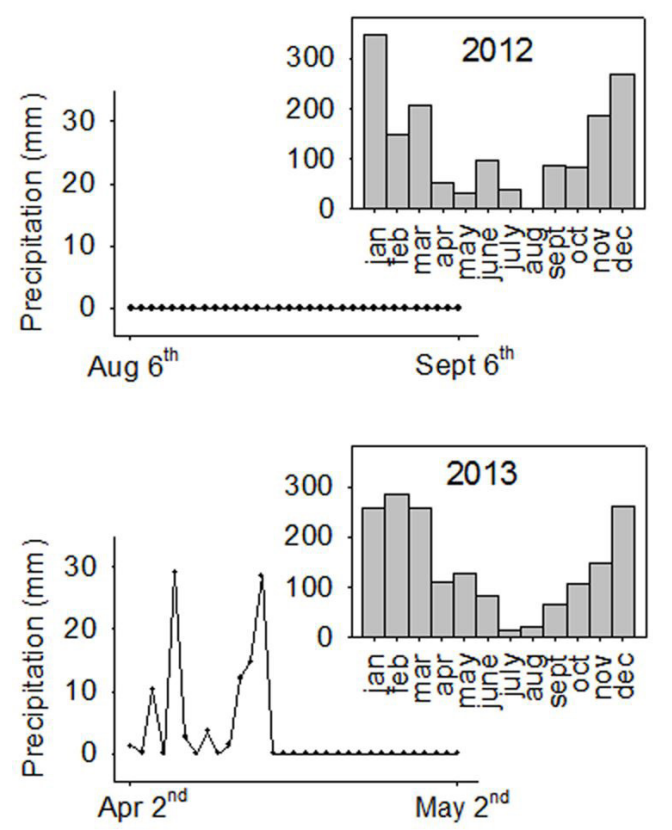

Figure 2. Daily rainfall $(\mathrm{mm})$ recorded in the month preceding each sampling date and annual rainfall $(\mathrm{mm})$ of the studied period.

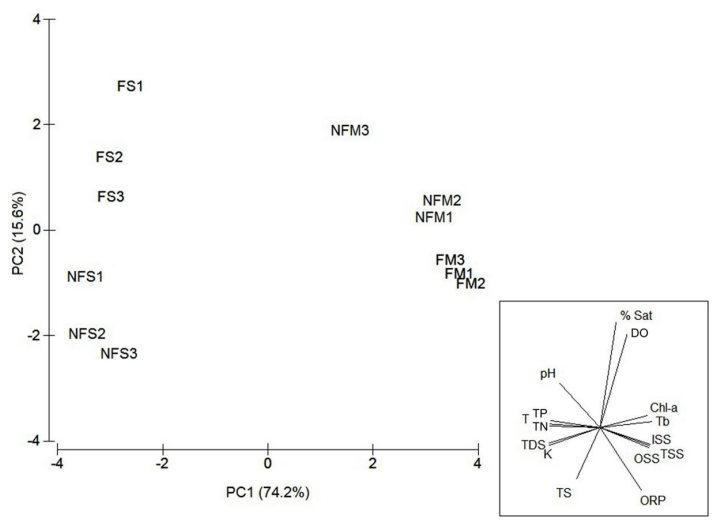

Figure 3. PCA based on the environmental parameters measured in the basaltic knickzones during the studied period. $\mathrm{F}=$ functional knickzone; $\mathrm{NF}=$ non-functional knickzone; $\mathrm{S}=$ September 2012; $\mathrm{M}=$ May 2013; $\mathrm{K}=$ conductivity; $\mathrm{Tb}=$ turbidity; $\mathrm{DO}=$ dissolved oxygen; $\%$ Sat $=$ oxygen saturation percentage; $\mathrm{T}=$ temperature; $\mathrm{ORP}=$ oxide reduction potential; $\mathrm{TDS}=$ total dissolved solids; $\mathrm{TN}=$ total nitrogen; $\mathrm{TP}=$ total phosphorus; $\mathrm{TS}=$ total solids; OSS $=$ organic suspended solids; ISS $=$ inorganic suspended solids; TSS $=$ total suspended solids; Chl-a $=$ chlorophyll $a$; $\mathrm{PC} 1=$ first principal component or principal component 1 ; $\mathrm{PC} 2=$ second principal component or principal component 2 . 
Table 1. Mean and standard deviation of the environmental parameters measured in the basaltic knickzones during the studied period.

\begin{tabular}{|c|c|c|c|c|}
\hline & \multicolumn{2}{|c|}{ Functional knickzone } & \multicolumn{2}{|c|}{ Non-functional knickzone } \\
\hline & Sept. 2012 & May 2013 & Sept. 2012 & May 2013 \\
\hline Depth $(\mathrm{m}){ }^{\dagger}$ & $0.46 \pm 0.16$ & - & $3.27 \pm 1.50$ & $2.93 \pm 1.27$ \\
\hline $\mathrm{pH}$ & $7.15 \pm 0.08^{\mathrm{a}}$ & $6.04 \pm 0.05^{\mathrm{b}}$ & $6.73 \pm 0.37^{\mathrm{a}}$ & $6.36 \pm 0.04^{b, c}$ \\
\hline $\mathrm{K}\left(\mathrm{mS} \mathrm{cm}^{-1}\right)$ & $94.00 \pm 0.00^{\mathrm{b}}$ & $57.33 \pm 0.58^{\mathrm{c}}$ & $103.33 \pm 0.58^{\mathrm{a}}$ & $56.33 \pm 0.58^{\mathrm{c}}$ \\
\hline $\mathrm{Tb}$ (NTU) & $13.40 \pm 3.55^{\mathrm{b}}$ & $48.83 \pm 1.33^{\mathrm{a}}$ & $12.00 \pm 0.20^{\mathrm{b}}$ & $41.17 \pm 5.20^{\mathrm{a}}$ \\
\hline $\mathrm{DO}\left(\mathrm{mg} \mathrm{L}^{-1}\right)$ & $9.33 \pm 0.61^{\mathrm{a}}$ & $9.10 \pm 0.31^{\mathrm{a}}$ & $7.79 \pm 0.34^{b}$ & $9.42 \pm 0.03^{\mathrm{a}}$ \\
\hline$\%$ Sat. & $110.33 \pm 6.86^{\mathrm{a}}$ & $103.10 \pm 3.48^{\mathrm{a}, \mathrm{b}}$ & $92.87 \pm 4.01^{\mathrm{b}}$ & $108.57 \pm 1.03^{\mathrm{a}}$ \\
\hline $\mathrm{T}\left({ }^{\circ} \mathrm{C}\right)$ & $22.53 \pm 0.21^{\mathrm{b}, \mathrm{d}}$ & $20.10 \pm 0.03^{\mathrm{b}, \mathrm{c}}$ & $23.09 \pm 0.4^{\mathrm{a}, \mathrm{d}}$ & $21.09 \pm 0.70^{\mathrm{a}, \mathrm{c}}$ \\
\hline ORP & $266.67 \pm 4.62^{b}$ & $325.67 \pm 3.51^{\mathrm{a}}$ & $287.67 \pm 18.72^{b}$ & $299.67 \pm 22.68^{\mathrm{b}}$ \\
\hline TDS (mg L-1) & $0.06 \pm 0.00^{\mathrm{b}}$ & $0.04 \pm 0.00^{\mathrm{c}}$ & $0.07 \pm 0.00^{\mathrm{a}}$ & $0.04 \pm 0.00^{\mathrm{c}}$ \\
\hline Chl-a $\left(\mu \mathrm{g} \mathrm{L}^{-1}\right)$ & $0.53 \pm 0.03^{\mathrm{c}}$ & $2.35 \pm 0.43^{\mathrm{b}}$ & $0.63 \pm 0.05^{\mathrm{c}}$ & $3.81 \pm 0.46^{\mathrm{a}}$ \\
\hline $\mathrm{TSS}\left(\mathrm{mg} \mathrm{L}^{-1}\right)$ & $5.30 \pm 0.36^{\mathrm{b}}$ & $25.11 \pm 3.62^{\mathrm{a}}$ & $5.75 \pm 1.08^{\mathrm{b}}$ & $19.27 \pm 7.76^{\mathrm{a}}$ \\
\hline OSS (mg L-1) & $1.61 \pm 0.09^{\mathrm{b}}$ & $5.58 \pm 0.58^{\mathrm{a}}$ & $1.99 \pm 0.62^{b}$ & $4.34 \pm 1.63^{\mathrm{a}}$ \\
\hline ISS (mg L-1) & $3.69 \pm 0.38^{\mathrm{b}}$ & $19.53 \pm 3.09^{\mathrm{a}}$ & $3.77 \pm 1.59^{b}$ & $14.93 \pm 6.14^{\mathrm{a}}$ \\
\hline $\mathrm{TS}\left(\mathrm{mg} \mathrm{L}^{-1}\right)$ & $67.00 \pm 3.00^{\mathrm{a}}$ & $66.00 \pm 10.39^{\mathrm{a}}$ & $73.67 \pm 6.11^{\mathrm{a}}$ & $57.00 \pm 7.94^{\mathrm{a}}$ \\
\hline $\mathrm{TN}\left(\mu \mathrm{g} \mathrm{L}^{-1}\right)$ & $1950 \pm 199.77^{\mathrm{b}, \mathrm{d}}$ & $588.55 \pm 24.74^{\mathrm{b}, \mathrm{d}}$ & $2160.50 \pm 83.23^{\mathrm{a}, \mathrm{c}}$ & $804.37 \pm 202.20^{\mathrm{a}, \mathrm{c}}$ \\
\hline $\mathrm{TP}\left(\mu \mathrm{g} \mathrm{L}^{-1}\right)$ & $19.96 \pm 0.35^{\mathrm{a}}$ & $17.05 \pm 0.44^{\mathrm{c}}$ & $20.30 \pm 0.35^{\mathrm{a}}$ & $18.28 \pm 0.19^{\mathrm{b}}$ \\
\hline
\end{tabular}

$\dagger$ Parameter not used in the statistical analysis. Different letters indicate significant differences in values of the same parameter (Tukey, $p<0.05$ ).

knickzones showed higher turbidity, dissolved oxygen, oxygen saturation, oxy-reduction potential, chlorophyll $a$, and total suspended matter and its organic and inorganic fractions.

\subsection{Macroinvertebrates}

Eighty-two taxa belonging to Cnidaria, Nemertea, Platyhelminthes, Nematoda, Annelida, Crustacea, Entognatha, Insecta and Mollusca were found considering both sampled areas. Seventy-two taxa occurred in the functional knickzone (38 exclusive) and forty-four in the non-functional (9 exclusive) (Appendix A).

The total density was higher in September in the functional knickzone and in May in the non-functional knickzone (Table 2). Diversity and equitability showed similar variation, with lower values in September in the non-functional knickzone (Table 2). The mean richness $(p=0.000 ; \mathrm{F}=17.12)$, density $(p=0.023 ; \mathrm{F}=5.36)$, Shannon diversity $(p=0.000 ; \mathrm{F}=13.82)$ and Pielou's equitability ( $p=0.001 ; \mathrm{F}=11.63)$ were significantly different in the interaction of knickzone-period, with higher values in the functional knickzone.

The relative abundance of Diptera was higher in the functional knickzone $(46 \%$ both in September and May), followed by Trichoptera ( $\mathrm{S}=23 \%$; $\mathrm{M}=19 \%$ ) and Ephemeroptera ( $\mathrm{S}=10 \% ; \mathrm{M}=23 \%$ ). The non-functional knickzone was dominated by Oligochaeta ( $\mathrm{S}=71 \%$; $\mathrm{M}=44 \%$ ) and Diptera ( $\mathrm{S}=18 \% ; \mathrm{M}=30 \%$ ) (Figure 4).

The NMDS analysis showed differences between the knickzones and periods in terms of the composition and structure of the macroinvertebrate community, which was verified by the ANOSIM test $(p<0.001)$ (Figure 5 ). The closer to 1 (maximum value) the $\mathrm{R}$ global value, the lower the probability that the distribution of samples is
Table 2. Total richness, density, diversity and equitability of macroinvertebrate community in each basaltic knickzone during the studied period.

\begin{tabular}{|c|c|c|c|c|}
\hline & \multicolumn{2}{|c|}{$\begin{array}{l}\text { Functional } \\
\text { knickzone }\end{array}$} & \multicolumn{2}{|c|}{$\begin{array}{c}\text { Non-functional } \\
\text { knickzone }\end{array}$} \\
\hline & $\begin{array}{l}\text { Sept. } \\
2012\end{array}$ & $\begin{array}{l}\text { May } \\
2013\end{array}$ & $\begin{array}{l}\text { Sept. } \\
2012\end{array}$ & $\begin{array}{l}\text { May } \\
2013\end{array}$ \\
\hline Richness & 65 & 45 & 28 & 34 \\
\hline Density & 2679 & 717 & 913 & 2513 \\
\hline Diversity & 2.83 & 2.56 & 1.67 & 2.87 \\
\hline Equitability & 0.27 & 0.33 & 0.16 & 0.41 \\
\hline
\end{tabular}

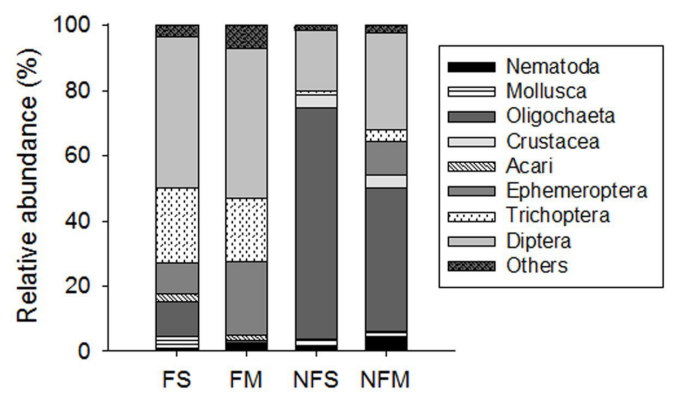

Figure 4. Relative abundance of the main macroinvertebrates taxonomic groups found in the basaltic knickzones during the studied period. $\mathrm{F}=$ functional knickzone; $\mathrm{NF}=$ non-functional knickzone; $\mathrm{S}=$ September 2012; $\mathrm{M}=$ May 2013 .

random, i.e., the higher the probability that the samples represent different communities (Clarke, 1993).

The average dissimilarity of the taxa density varied between 73.64 and $93.40 \%$ (SIMPER analysis, Table 3). 
(a) Community composition
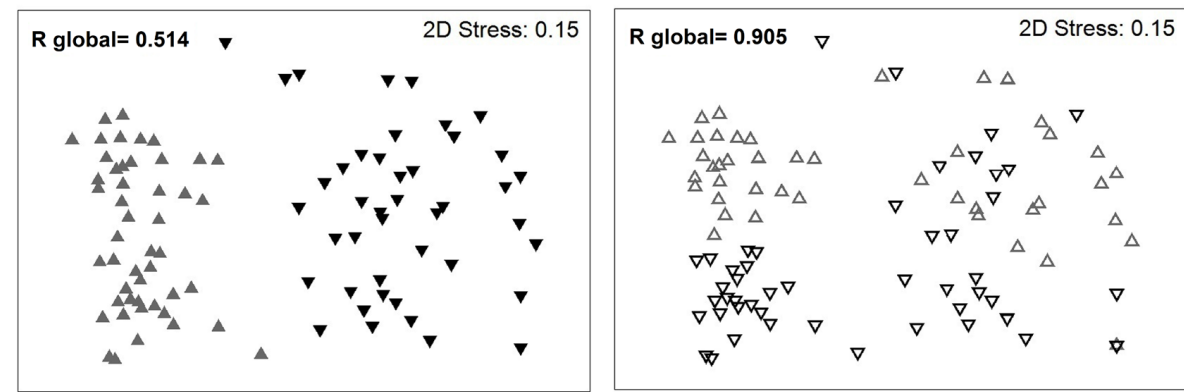

(b) Community structure
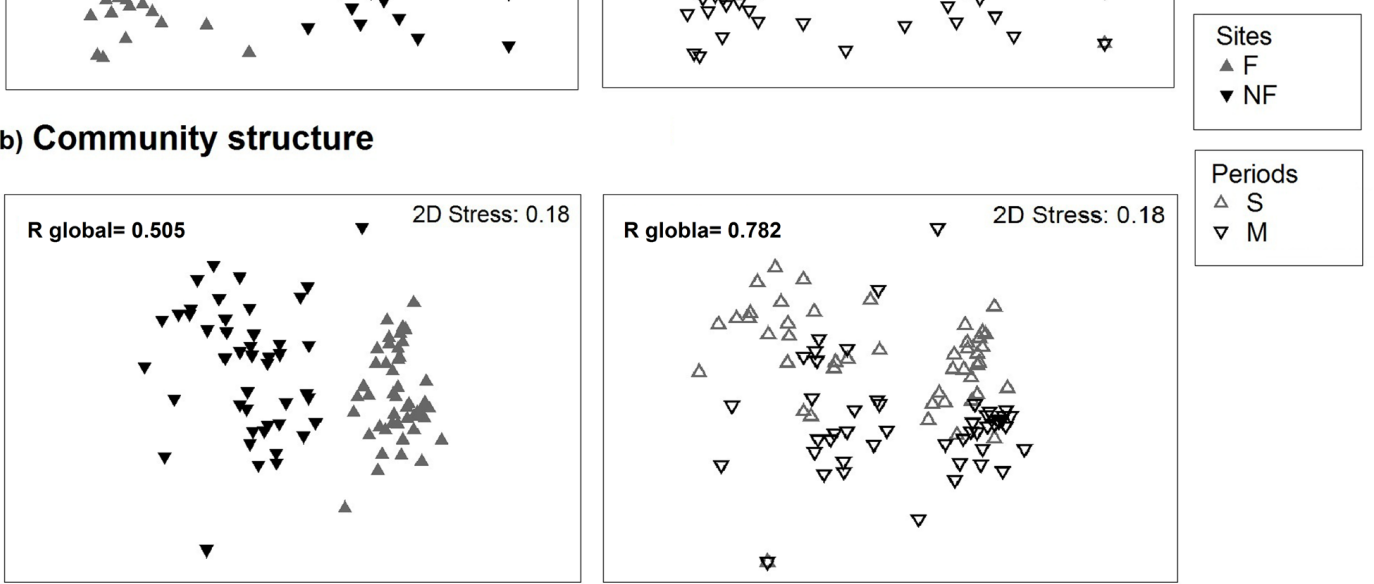

\begin{tabular}{|ll|}
\hline \multicolumn{2}{|c|}{ Periods } \\
$\Delta$ & $\mathrm{S}$ \\
$\nabla$ & $\mathrm{M}$ \\
\hline
\end{tabular}

Figure 5. Ordination diagram (NMDS) of macroinvertebrates in knickzones and sampling periods, regarding composition (a) and community structure (b). R global values at ANOSIM test is also shown. $\mathrm{F}=$ functional knickzone; $\mathrm{NF}=$ non-functional knickzone; $\mathrm{S}=$ September 2012; $\mathrm{M}=$ May 2013.

Table 3. Average dissimilarity values between knickzones and periods studied, according SIMPER analyses.

\begin{tabular}{ccccc}
\hline \multicolumn{5}{c}{ Average dissimilarity (\%) } \\
\hline Knickzones/Periods & FS & FM & NFS & NFM \\
\hline FS & - & 73.64 & 91.34 & 85.54 \\
FM & & - & 93.40 & 90.17 \\
NFS & & & - & 84.53 \\
NFM & & & & - \\
\hline
\end{tabular}

FS $=$ Functional knickzone in September 2012; FM=Functional knickzone in May 2013; NFS = Non-functional knickzone in September 2012; NFM = Non-functional knickzone in May 2013.

Chironomidae n.i. (Diptera), Orthocladiinae (Diptera), Chironominae (Diptera), Smicridea (Trichoptera), Simuliidae (Diptera), Traverhyphes (Ephemeroptera), Camelobaetidius (Ephemeroptera), Nematoda and Diptera (pupae) were the taxa identified as being responsible for the observed dissimilarity (Table 4, Figure 6).

\section{Discussion}

The results demonstrate that most environmental parameters were similar between the basaltic knickzones within each seasonal period. However, in terms of macroinvertebrates fauna differences between the functional and non-functional knickzones were evident.
Table 4. SIMPER values (square-root transformed density raw data) showing the main taxa contributing to similarity in macroinvertebrate communities within each basaltic knickzone in the studied period.

\begin{tabular}{cccc}
\hline $\begin{array}{c}\text { Average } \\
\text { similarity } \\
(\%)\end{array}$ & Taxa & $\begin{array}{c}\text { Average } \\
\text { density }\end{array}$ & $\begin{array}{c}\text { Contribution } \\
(\%)\end{array}$ \\
\hline FS & Orthocladiinae & 487.96 & 35.06 \\
$(40.18)$ & Chironominae & 415.74 & 15.92 \\
& Smicridea & 536.11 & 11.70 \\
& Chironomidae n.i. & 120.37 & 8.96 \\
& Traverhyphes & 136.11 & 5.75 \\
FM & Simuliidae & 162.04 & 22.42 \\
$(44.83)$ & Orthocladiinae & 101.85 & 21.98 \\
& Camelobaetidius & 125.93 & 19.77 \\
& Smicridea & 74.54 & 13.01 \\
& Chironominae & 34.72 & 7.19 \\
NFS & Chironominae & 61.03 & 89.85 \\
$(10.66)$ & Orthocladiinae & 31.57 & 6.50 \\
& & & \\
NFM & Chironominae & 555.56 & 76.42 \\
$(30.15)$ & Nematoda & 103.11 & 12.03 \\
& Diptera (pupae) & 56.82 & 8.05 \\
\hline
\end{tabular}

FS $=$ Functional knickzone in September 2012; FM=Functional knickzone in May 2013; NFS = Non-functional knickzone in September 2012; NFM = Non-functional knickzone in May 2013. 

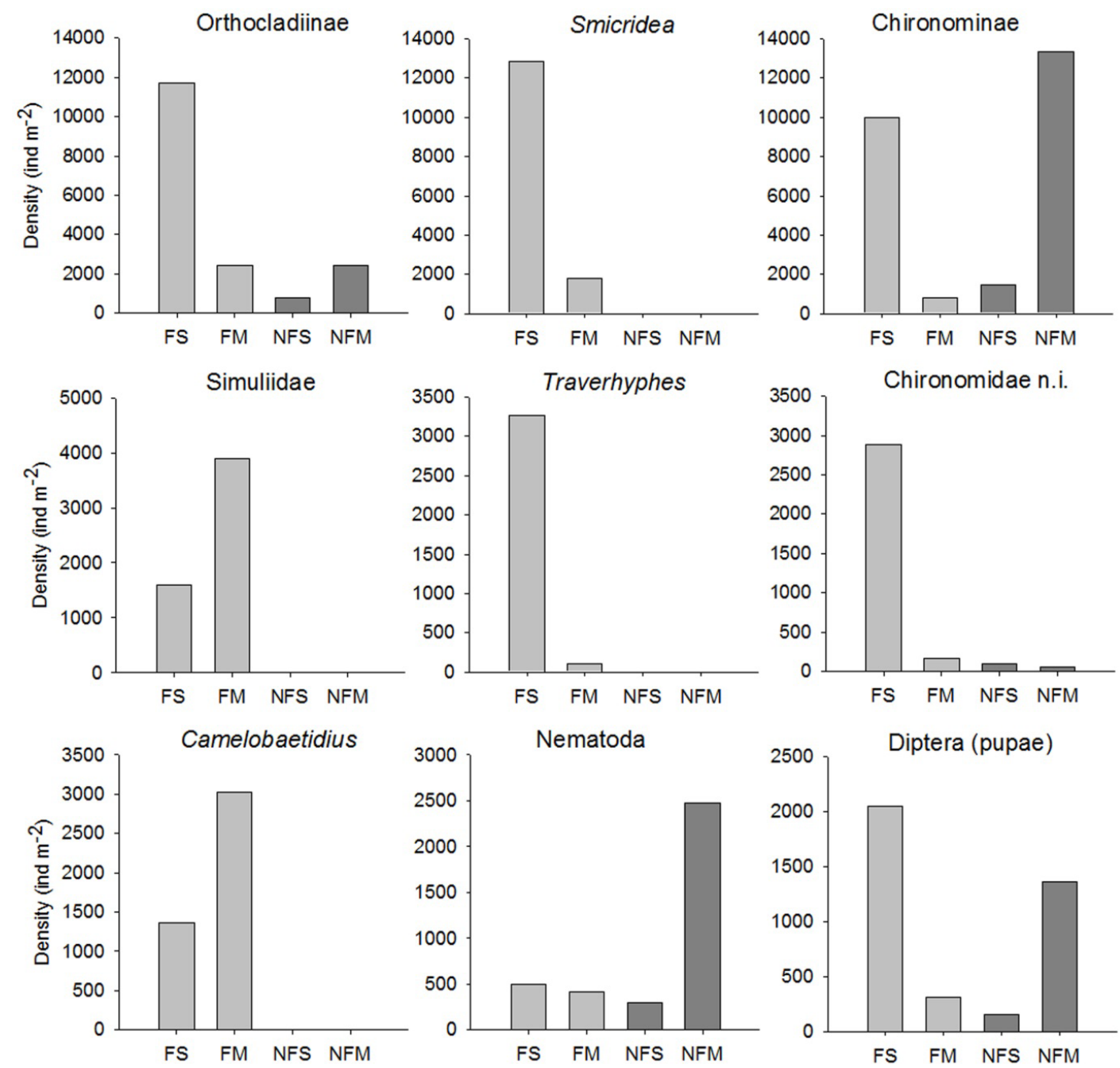

Figure 6. Graphical representation of the total density of macroinvertebrate taxa with contribution $>5 \%$ for the dissimilarity of the knickzones during the studied period. $\mathrm{F}=$ functional knickzone; $\mathrm{NF}=$ non-functional knickzone; $\mathrm{S}=\mathrm{September} 2012$; M = May 2013 .

The non-functional knickzone exhibits lower mean values of richness, density and diversity of macroinvertebrates.

The physical and chemical similarities in the water parameters of the two knickzones within each seasonal period likely occur because of the low retention time of water in the run-of-river reservoir of the Palmeiras SHP (mean of 2.06 days). Nogueira et al. (2012), when studying the Salto Grande Reservoir of the Paranapanema River (SE, Brazil), observed that the entire reservoir functions as a riverine system as result of the short water retention time. Therefore, although the non-functional knickzone is under the direct influence of an SHP reservoir, the environmental parameters did not change significantly. Conversely, temporal differences were evident by the PCA and two-way ANOVA results, showing the effects of seasonality. The conditions found in September 2012 can be considered typical of the dry season, while the data observed in May 2013 reflect the end of the rainy season.
Seasonality can alter not only the physical and chemical parameters, as volume, flow and the speed of water displacement. These natural dynamics of the fluctuation in water levels in lotic systems also influences the dispersion processes of organisms, locally changing the composition and structure of communities (Modde and Schmulbach, 1973; Lucca et al., 2010). In our study, the total richness, abundance and diversity of aquatic macroinvertebrates were lower in the functional knickzone in May 2013 compared to September 2012. The opposite was observed in the non-functional knickzone. Probably these results reflected passive downstream transportation of benthic organisms from the upstream knickzone during the rainy season.

However, the settlement of these dispersed organisms probably is not stable, as the mean values of macroinvertebrate richness, density and diversity were consistently lower in the non-functional knickzone (ANOSIM and SIMPER analyses). Organisms reaching the non-functional knickzone 
will most likely die, only remaining the most resistant taxa. The presence of dams disrupts rivers longitudinal connectivity (Vannote et al., 1980; Stanford and Ward, 2001), causing considerable environmental changes including fauna segregation.

The disruption of the longitudinal connectivity leads fragmentation (Anderson et al., 2015), interfering with the natural downstream movement of mineral sediments (Skalak et al., 2009; Csiki and Rhoads, 2010) and distribution of particulate organic matter (Pohlon et al., 2007), nutrients (Stanley and Doyle, 2002), plant propagules (Jansson et al., 2000) and aquatic species (Benstead et al., 1999; O'Connor et al., 2006). In this way, the transference of effects should be an important ecological aspect to be considered in evaluations of impacts and cascading effects from multiple SHPs installed along a river (Naliato et al., 2009; Nogueira et al., 2012; Anderson et al., 2015).

The presence of dams changes water flow patterns, with direct influence on the depth and nature of the bottom substrate. The permanent flooded condition in the non-functional knickzone means a loss of the natural fluctuation dynamics of water level related to weather changes. This process can act as a disturbance in the functional knickzone, which would promote biodiversity and renewal processes in these environments (Holling and Meffe, 1996; Paine et al., 1998). A decrease in the heterogeneity of substrates may have acted as a factor reducing the abundance and diversity of macroinvertebrates in the non-functional knickzone too. Changes in the nature of the substrate is a consequence of damming because higher water retention time and velocity decrease result in the accumulation of fine and homogeneous sediments (Thornton, 1990; Csiki and Rhoads, 2010; Mueller et al., 2011). Thereby, a loss of habitats and the associated resources available for the animals can result in a simplification and homogenization of biodiversity, which will present lower evenness and higher dominance of some groups, as recorded in the non-functional knickzone.

Ecological theory predicts that habitat complexity allows more species to co-exist in a given area (Pianka, 1999; Muehlbauer and Doyle, 2012), corroborating our finding of 72 taxa in the functional knickzone. The large number of exclusive taxa also indicated that this kind of macrohabitat may support differential local distribution patterns (Muehlbauer and Doyle, 2012). The presence of knickzones allows filter-feeding groups, such as Hydropsychidae (caddisflies) or Simuliidae (black flies), to persist despite their absence in other lentic compartments that are under direct reservoir influence. Two dominant groups exhibiting this pattern are the EPT taxa (Hydropsychidae and Baetidae). Therefore, a knickzone, such as the knickpoints studied by Muehlbauer and Doyle (2012), might be considered as a regional hotspot in terms of biodiversity and ecosystem health metrics (e.g., EPT - Lenat, 1988; Lenat and Penrose, 1996).

Fluvial systems integrate landscapes and can exhibit distinct structural and functional stretches along their courses. Knickzones are environments that have intrinsic ecological characteristics, which have been scientifically unexplored because the difficulties of access and methodological constraints - impossibility to apply standard sampling techniques to the distinct habitats (Brambilla et al., 2018). The precautionary principle (CNUMAD, Rio-92) calls for early measures to avoid and mitigate environmental damage in the face of the uncertainty. However, the conservation of particular river stretches or even an entire river, with a focus on the existing biota, is a challenging task in some countries. In Brazil, the official system for continental protected areas is basically directed towards terrestrial ecosystems, and river protection is therefore not a specific target.

Furthermore, the knowledge about SHP is still inconsistent all over the word. According to Kelly-Richards et al. (2017), there is a need for deeper qualitative understanding of SHP impacts in diverse contexts. Our study indicates that the SPH expansion, including reservoir cascade systems, can be a considerable threat to the knickzones, causing irreversible losses in the associated biota.

\section{Acknowledgements}

We thank Dr. Gilmar Perbiche Neves for useful suggestions in this manuscript, Dr. Danilo Augusto de Oliveira Naliato and MSc. Marco Aurelio Pessotto for help in field work and CAPES for a scholarship granted to the first author.

\section{References}

AMERICAN PUBLIC HEALTH ASSOCIATION -APHA, 2012. Standard methods for the examination of water and wastewater. 22nd ed. Washington: APHA. 1496 p.

ANDERSON, A.J., GORLEY, R.N. and CLARKE, K.R., 2008. Permanova+for Primer: guide to software and statistical methods. Plymouth: PRIMER-E. 214 p.

ANDERSON, D., MOGGRIDGE, H., WARREN, P. and SHUCKSMITH, J., 2015. The impacts of 'run-of-river' hydropower on the physical and ecological condition of rivers. Water and Environment Journal, vol. 29, no. 2, pp. 268-276. http://dx.doi. org/10.1111/wej.12101.

BENSTEAD, J., MARCH, J., PRINGLE, C. and SCATENA, F., 1999. Effects of a low-head dam and water abstraction on migratory tropical stream biota. Ecological Applications, vol. 9, no. 2, pp. 656-668. http://dx.doi.org/10.1890/1051-0761(1999)009[0656:EO ALHD]2.0.CO;2.

BRAMBILLA, E.M., RUOCCO, A.M.C. and NOGUEIRA, M.G., 2018. A contribution for the limnological knowledge of basaltic knickzones. Brazilian Journal of Biology $=$ Revista Brasileira de Biologia, vol. 78, no. 2, pp. 375-385. http://dx.doi. org/10.1590/1519-6984.172985. PMid:28793033.

BRANDIMARTE, A.L., SHIMIZU, G.Y., ANAYA, M. and KUHLMANN, M.L., 2004. Amostragem de invertebrados bentônicos. In: E.M. BICUDO and D.C. BICUDO, eds. Amostragem em Limnologia. São Carlos: RiMa, pp. 213-228.

BRINKHURST, R.O. and MARCHESE, M.R., 1989. Guia para la identificación de oligoquetos acuáticos continentales de Sud y Centroamérica. Santa Fé: Clímax. 207 p. 
CALLISTO, M., GOULART, M., MEDEIROS, A., MORENO, P. and ROSA, C., 2004. Diversity assessment of benthic macroinvertebrates, yeasts, and microbiological indicators along a longitudinal gradient in Serra do Cipó, Brazil. Brazilian Journal of Biology $=$ Revista Brasileira de Biologia, vol. 64, no. 4, pp. 743-755. http://dx.doi.org/10.1590/S1519-69842004000500003. PMid:15744414.

CLARKE, K. and WARWICK, R.M., 2001. Change in marine communities: an approach to statistical analysis and interpretation. 2nd ed. Plymouth: PRIMER-E. 172 p.

CLARKE, K.R. and GORLEY, R.N., 2006. PRIMER v6: user manual/tutorial. Plymouth: PRIMER-E. 192 p.

CLARKE, K.R., 1993. Non-parametric multivariate analyses of changes in community structure. Australian Journal of Ecology, vol. 18, no. 1, pp. 117-143. http://dx.doi.org/10.1111/j.1442-9993.1993. tb00438.x.

COLE, G.A., 1979. Textbook of limnology. Saint-Louis: Mosby Company. 426 p.

CSIKI, S. and RHOADS, B., 2010. Hydraulic and geomorphological effects of run-of-river dams. Progress in Physical Geography, vol. 34, no. 6, pp. 55-780. http://dx.doi.org/10.1177/0309133310369435.

DOMÍNGUEZ, E. and FERNÁNDEZ, H.R., 2009. Macroinvertebrados bentónicos sudamericanos: sistemática y biología. Tucumán: Fundación Miguel Lillo. 656 p.

ESTEVES, F., 2011. Fundamentos de limnologia. 3. ed. Rio de Janeiro: Interciência. 826 p.

HAMMER, Ø., HARPER, D.A.T. and RYAN, P.D., 2001 [viewed 23 July 2014]. PAST: paleontological statistics software package for education and data analysis. Palaeontologia Electronica [online], vol. 4, no. 1, pp. 4-9. Available from: http://palaeo-electronica. org/2001_1/past/issue1_01.htm

HAYAKAWA, Y.S. and OGUCHI, T., 2006. DEM-based identification of fluvial knickzones and its application to Japanese mountain rivers. Geomorphology, vol. 78, no. 1-2, pp. 90-106. http://dx.doi.org/10.1016/j.geomorph.2006.01.018.

HAYAKAWA, Y.S. and OGUCHI, T., 2009. GIS analysis of fluvial knickzone distribution in Japanese mountain watersheds. Geomorphology, vol. 111, no. 1-2, pp. 27-37. http://dx.doi. org/10.1016/j.geomorph.2007.11.016.

HOLling, C.S. and MEFFE, G.K., 1996. Command and control and the pathology of natural resource management. Conservation Biology, vol. 10, no. 2, pp. 328-337. http://dx.doi. org/10.1046/j.1523-1739.1996.10020328.x.

INSTITUTO NACIONAL DE METEOROLOGIA - INMET [online], 2014 [viewed 23 July 2014]. Available from: http:// www.inmet.gov.br/portal/

JANSSON, R., NILSSON, C., DYNESIUS, M. and ANDERSSON, E., 2000. Effects of river regulation on river-margin vegetation: a comparison of eight boreal rivers. Ecological Applications, vol. 10 , no. 1 , pp. 203-224. http://dx.doi.org/10.1890/10510761(2000)010[0203:EORROR]2.0.CO;2.

JESUS, T., FORMIGO, N., SANTOS, P. and TAVARES, G.R., 2004. Impact evaluation of the Vila Viçosa small hydroelectric power plant (Portugal) on the water quality and on the dynamics of the benthic macroinvertebrate communities of the Ardena river. Limnetica, vol. 23, pp. 241-256.

KELLY-RICHARDS, S., SILBER-COATS, N., CROOTOF, A., TECKLIN, D. and BAUER, C., 2017. Governing the transition to renewable energy: a review of impacts and policy issues in the small hydropower boom. Energy Policy, vol. 101, pp. 251-264. http://dx.doi.org/10.1016/j.enpol.2016.11.035

KRANTZ, G.W. and WALTER, D.E., 2009. A manual of acarology. 3rd ed. Lubbock: Texas Tech University Press. 807 p.

LENAT, D.R. and PENROSE, D.L., 1996. History of the EPT taxa richness metric. Bulletin of the North American Benthological Society, vol. 13, pp. 305-307.

LENAT, D.R., 1988. Water quality assessment of streams using a qualitative collection method for benthic macroinvertebrates. Journal of the North American Benthological Society, vol. 7, no. 3, pp. 222-233. http://dx.doi.org/10.2307/1467422.

LIMA, A.G. and BINDA, A.L., 2013. Lithologic and structural controls on fluvial knickzones in basalts of the Parana Basin, Brazil. Journal of South American Earth Sciences, vol. 48, pp. 262-270. http://dx.doi.org/10.1016/j.jsames.2013.10.004.

LOPRETTO, E.C. and TELL, G., 1995. Ecosistemas de aguas continentales: metodologías para su estudio, tomo II. La Plata: Ediciones Sur. 1401 p.

LUCCA, J.V., PAMPLIN, P.A.Z., GESSNER, A.F., TRIVINHOSTRIXINO, S., SPADANO-ALBUQUERQUE, A.L. and ROCHA, O., 2010. Benthic macroinvertebrates of a tropical lake: Lake Caçó, MA, Brazil. Brazilian Journal of Biology = Revista Brasileira de Biologia, vol. 70, no. 3, pp. 593-600. http:// dx.doi.org/10.1590/S1519-69842010000300016. PMid:20730346.

MACKERETH, F.J.H., HERON, J. and TALLING, F.J., 1989. Water analysis: some revised methods for limnologists. 2nd ed. Ambleside: Freshwater Biological Association. 120 p.

MANTEL, S.K., HUGHES, D.A. and MULLER, N.W.J., 2010. Ecological impacts of small dams on South African rivers. Part 1: drivers of change: water quantity and quality. Water S.A., vol. 36, pp. 351-360.

MARIANO, R. and FROEHLICH, C.G., 2007 [viewed 23 July 2014]. Ephemeroptera. In: C.G. FROEHLICH, ed. Guia online: Identificação de larvas de insetos aquáticos do Estado de São Paulo [online]. Ribeirão Preto: USP. Available from: http://sites. ffclrp.usp.br/aguadoce/Guia_online/

MERRITT, R.W. and CUMMINS, K.W., 1996. An introduction to the aquatic insects of North America. 3rd ed. Dubuque: Kendall/ Hunt Publishing Company. $722 \mathrm{p}$.

MODDE, T.C. and SCHMULBACH, J.C., 1973. Seasonal changes in the drift and benthic macroinvertebrates in the unchannelized Missouri river in South Dakota. Proceedings of the South Dakota Academy of Science, vol. 52, pp. 118-126.

MUEHLBAUER, J.D. and DOYLE, M.W., 2012. Knickpoint effects on macroinvertebrates, sediment, and discharge in urban and forested streams: urbanization outweighs microscale habitat heterogeneity. Freshwater Science, vol. 31, no. 2, pp. 282-295. http://dx.doi.org/10.1899/11-010.1

MUELLER, M., PANDER, J. and GEIST, J., 2011. The effects of weirs on structural stream habitat and biological communities. Journal of Applied Ecology, vol. 48, no. 6, pp. 1450-1461. http:// dx.doi.org/10.1111/j.1365-2664.2011.02035.x. PMid:21941744.

MUGNAI, R., NESSIMIAN, J.L. and BAPTISTA, D.F., 2010. Manual de identificação de macroinvertebrados aquáticos do Estado do Rio de Janeiro. Rio de Janeiro: Technical Books Editora. $174 \mathrm{p}$. 
NALIATO, D.A.O., NOGUEIRA, M.G. and PERBICHENEVES, G., 2009. Discharge pulses of hydroelectric dams and their effects in the downstream limnological conditions: a case study in a large tropical river (SE Brazil). Lakes and Reservoirs, vol. 14, no. 4, pp. 301-314. http://dx.doi.org/10.1111/j.14401770.2009.00414.x.

NOGUEIRA, M.G., PERBICHE-NEVES, G. and NALIATO, D.A.O., 2012. Limnology of two contrasting hydroelectric reservoirs (Storage and run-of-rivers) in Southeast Brazil. In: H. SAMADIBOROUJEN, ed. Hydropower: practice and application. Rijeka: InTech, pp. 167-184. http://dx.doi.org/10.5772/31829.

O'CONNOR, J., O’MAHONY, D., O’MAHONY, J. and GLENANE, T., 2006. Some impacts of low and medium head weirs on downstream fish movement in the Murray-Darling Basin in Southeastern Australia. Ecology Freshwater Fish, vol. 15, no. 4, pp. 419-427. http://dx.doi.org/10.1111/j.1600-0633.2006.00162.x.

PAINE, R.T., TEGNER, M.J. and JOHNSON, E.A., 1998. Compounded perturbations yield ecological surprises. Ecosystems, vol. 1, no. 6, pp. 535-545. http://dx.doi.org/10.1007/s100219900049.

PEDERSON, J.L. and TRESSLER, C., 2012. Colorado River long-profile metrics, knickzones and their meaning. Earth and Planetary Science Letters, vol. 345-348, pp. 171-179. http:// dx.doi.org/10.1016/j.epsl.2012.06.047.

PENNAK, R.W., 1989. Fresh-water invertebrates of the United States: Protozoa to Mollusca. 3rd ed. New-York: WileyInterscience. $656 \mathrm{p}$.

PIANKA, E.R., 1999. Evolutionary ecology. 6th ed. San Francisco: Benjamin Cummings. 512 p.

POHLOn, E., AUgSpurger, C., Risse-BUhl, U., ARLE, J., WILLKOMM, M., HALLE, S. and KUSEL, K., 2007. Querying the obvious: lessons from a degraded stream. Restoration Ecology, vol. 15, no. 2, pp. 312-316. http://dx.doi. org/10.1111/j.1526-100X.2007.00215.X.

PREMALATHA, M., TABASSUM-ABBASI., ABBASI, T. and ABBASI, S.A., 2014. A critical view on the eco-friendliness of small hydroelectric installations. The Science of the Total Environment, vol. 481, pp. 638-643. http://dx.doi.org/10.1016/j. scitotenv.2013.11.047. PMid:24332792.

ROSENBERG, D.M. and RESH, V.H., 1993. Introdution to freshwater biomonitoring and benthic macroinvertebrates. In: D.M. ROSENBERG and V.H. RESH, eds. Freshwater biomonitoring and benthic macroinvertebrates. New York: Chapman \& Hall, pp. 1-9.

SKALAK, K., PIZZUTO, J. and HART, D., 2009. Influence of small dams on downstream characteristics in Pennsylvania and Maryland: implications for the long term geomorphic effects of dam removal. Journal of the American Water Resources Association, vol. 45 , no. 1 , pp. 97-109. http://dx.doi.org/10.1111/j.17521688.2008.00263.x.

SPÄNHOF, B., 2014. Current status and future prospects of hydropower in Saxony (Germany) compared to trends in Germany, the European Union and the World. Renewable \& Sustainable Energy Reviews, vol. 30, pp. 518-525. http://dx.doi.org/10.1016/j. rser.2013.10.035.
STANFORD, J. and WARD, J., 2001. Revisiting the serial discontinuity concept. Regulated Rivers: Research and Management, vol. 17, no. 4-5, pp. 303-310. http://dx.doi.org/10.1002/rrr.659.

STANLEY, E. and DOYLE, M., 2002. A geomorphic perspective on nutrient retention following dam removal. Bioscience, vol. 52, no. 8, pp. 693-701. http://dx.doi.org/10.1641/00063568(2002)052[0693:AGPONR]2.0.CO;2.

STATSOFT, 2004 [viewed 23 July 2014]. Statistica (data analysis software system), version 7 [online]. 8. Available from: www. statsoft.com

STRICKLAND, J.D. and PARSONS, T.R., 1960. A manual of sea water analysis. Fisheries Research Board of Canada, vol. 125, pp. 1-185. http://dx.doi.org/10.1002/iroh.19610460322.

TALLING, J.F. and DRIVER, D., 1961. Some problems in the estimation of chlorophyll a in phytoplankton. In: M.S. DOTY, ed. Proceedings of the Conference on Primary Productivity Measurements in Marine and Freshwater, 1961, Hawaii. Hawaii: U.S. Atomic Energy Commission, pp. 142-146.

THORNTON, W.K., 1990. Perspectives on reservoir limnology. In: K.W. THORNTON, B.L. KIMMEL and E.F. PAYNE, eds. Reservoir limnology: ecological perspectives. New York: John Wiley \& Sons, pp. 1-13.

VANNOTE, R., MINSHALL, G., CUMMINS, K., SEDELL, J. and CUSHING, C., 1980. The River Continuum Concept. Canadian Journal of Fisheries and Aquatic Sciences, vol. 37, no. 1, pp. 130-137. http://dx.doi.org/10.1139/f80-017.

WALSH, L.S., MARTIN, A.J., OJHA, T.P. and FEDENCZUK, T., 2012. Correlations of fluvial knickzones with landslide dams, lithologic contacts, and faults in the southwestern Annapurna Range, central Nepalese Himalaya. Journal of Geophysical Research, vol. 117, no. F1, pp. F01012. http://dx.doi.org/10.1029/2011JF001984.

WinEMiller, K.O., MCINTYRE, P.B., CASTELlO, L., FLUET-CHOUINARD, E., GIARRIZZO, T., NAM, S., BAIRD, I.G., DARWALL, W., LUJAN, N.K., HARRISON, I., STIASSNY, M.L.J., SILVANO, R.A.M., FITZGERALD, D.B., PELICICE, F.M., AGOSTINHO, A.A., GOMES, L.C., ALBERT, J.S., BARAN, E., PETRERE, M., ZARFL, C., MULLIGAN, M., SULLIVAN, J.P., ARANTES, C.C., SOUSA, L.M., KONING, A.A., HOEINGHAUS, D.J., SABAJ, M., LUNDBERG, J.G., ARMBRUSTER, J., THIEME, M.L., PETRY, P., ZUANON, J., VILARA, G.T., SNOEKS, J., OU, C., RAINBOTH, W., PAVANELLI, C.S., AKAMA, A., SOESBERGEN, A. and SAENZ, L., 2016. Balancing hydropower and biodiversity in the Amazon, Congo, and Mekong. Science, vol. 351, no. 6269, pp. 128129. http://dx.doi.org/10.1126/science.aac7082. PMid:26744397.

ZAR, J.H., 1999. Bioestatistical analysis. 4th ed. New Jersey: Prentice Hall. 663 p.

ZARFL, C., LUMSDON, A.E., BERLEKAMP, J., TYDECKS, L. and TOCKNER, K., 2015. A global boom in hydropower dam construction. Aquatic Sciences, vol. 77, no. 1, pp. 161-170. http:// dx.doi.org/10.1007/s00027-014-0377-0. 
Appendix A. Occurrence of macroinvertebrates in the functional and non-functional basaltic knickzones during the studied period.

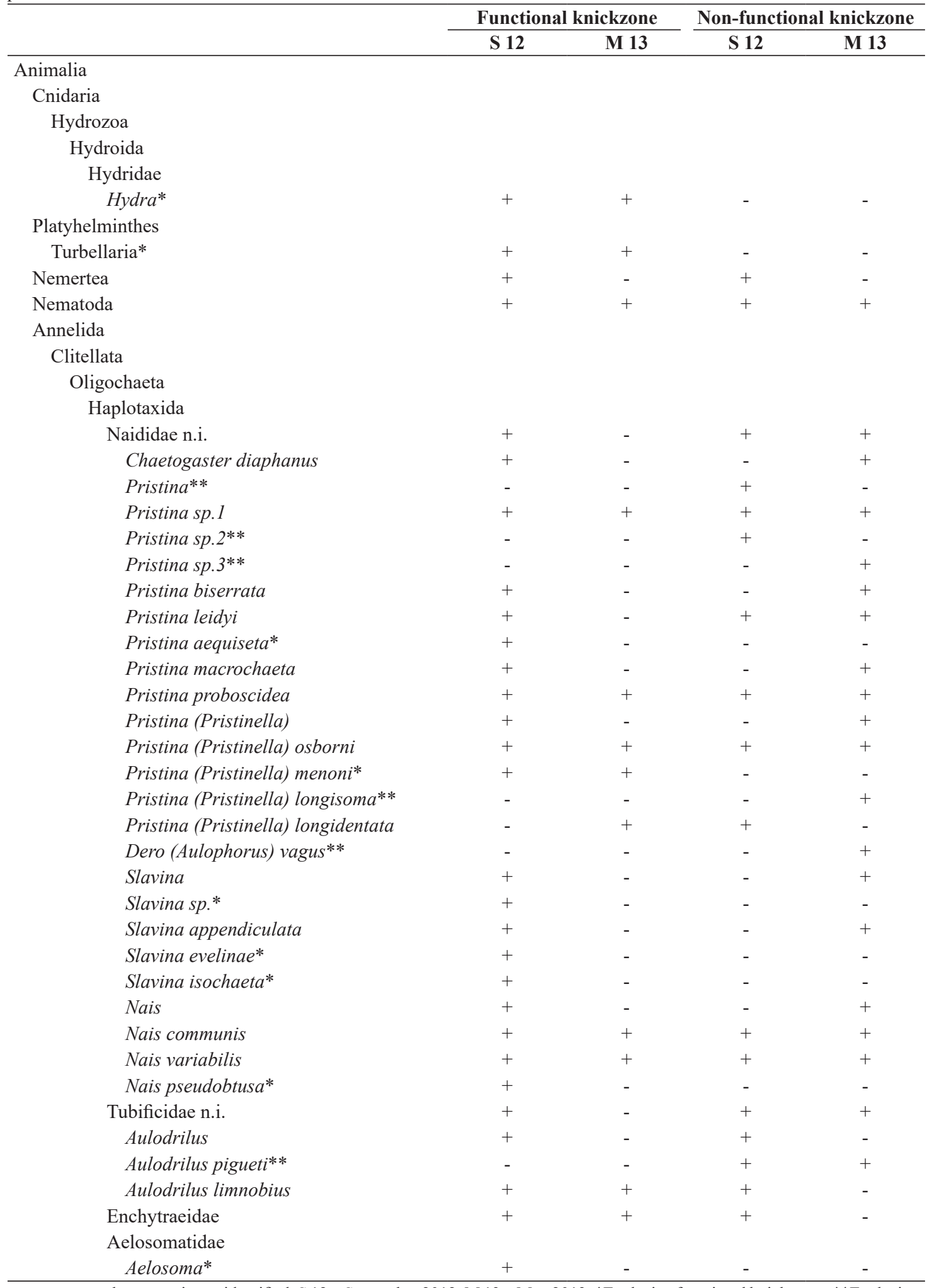

+ presence; - absence; n.i.: not identified; S 12 = September 2012; M 13 = May 2013; *Exclusive functional knickzone; **Exclusive non-functional knickzone. 
$\underline{\text { Appendix A. Continued... }}$

\begin{tabular}{|c|c|c|c|c|}
\hline & \multicolumn{2}{|c|}{ Functional knickzone } & \multicolumn{2}{|c|}{ Non-functional knickzone } \\
\hline & S 12 & M 13 & S 12 & M 13 \\
\hline Hirudinida & + & + & + & + \\
\hline \multicolumn{5}{|l|}{ Arthropoda } \\
\hline \multicolumn{5}{|l|}{ Crustacea } \\
\hline \multicolumn{5}{|l|}{ Branchiopoda } \\
\hline Diplostraca & - & + & - & + \\
\hline \multicolumn{5}{|l|}{ Maxillopoda } \\
\hline Ostracoda & + & - & + & + \\
\hline \multicolumn{5}{|l|}{ Arachnida } \\
\hline \multicolumn{5}{|l|}{ Acari } \\
\hline \multicolumn{5}{|l|}{ Sarcoptiformes } \\
\hline Oribatida & + & + & + & + \\
\hline \multicolumn{5}{|l|}{ Trombidiformes } \\
\hline Hydrachnidae & + & + & - & + \\
\hline \multicolumn{5}{|l|}{ Entognatha } \\
\hline \multicolumn{5}{|l|}{ Collembola } \\
\hline Isotomidae* & + & + & - & - \\
\hline Entomobryidae* & - & + & - & - \\
\hline Sminthuridae* & - & + & - & - \\
\hline \multicolumn{5}{|l|}{ Insecta } \\
\hline Odonata n.i.* & - & + & - & - \\
\hline Aeshnidae* & + & - & - & - \\
\hline Gomphidae & + & + & - & + \\
\hline Libellulidae & + & + & + & + \\
\hline Ephemeroptera n.i.* & + & - & - & - \\
\hline Baetidae n.i.* & + & + & - & - \\
\hline Camelobaetidius* & + & + & - & - \\
\hline Americabaetis* & + & + & - & - \\
\hline Baetodes* & + & + & - & - \\
\hline \multicolumn{5}{|l|}{ Caenidae } \\
\hline Caenis** & - & - & - & + \\
\hline \multicolumn{5}{|l|}{ Leptohyphidae } \\
\hline Traverhyphes* & + & + & - & - \\
\hline Leptophebiidae n.i. & - & + & - & + \\
\hline Hagenulopsis* & + & + & - & - \\
\hline \multicolumn{5}{|l|}{ Oligoneuriidae } \\
\hline Lachlania* & - & + & - & - \\
\hline \multicolumn{5}{|l|}{ Megaloptera } \\
\hline \multicolumn{5}{|l|}{ Corydalidae } \\
\hline Corydalus* & + & - & - & - \\
\hline Trichoptera n.i.* & + & + & - & - \\
\hline Leptoceridae $n . i^{* *}$ & - & - & - & + \\
\hline Nectopsyche & - & + & + & + \\
\hline Glossomatidae n.i.* & - & + & - & - \\
\hline Culoptila* & + & - & - & - \\
\hline Mexitrichia* & + & + & - & - \\
\hline \multicolumn{5}{|l|}{ Helicopsychidae } \\
\hline Helicopsyche & + & - & - & + \\
\hline Hydroptilidae n.i. & + & + & - & + \\
\hline Oxyethira & + & + & + & - \\
\hline
\end{tabular}


Appendix A. Continued...

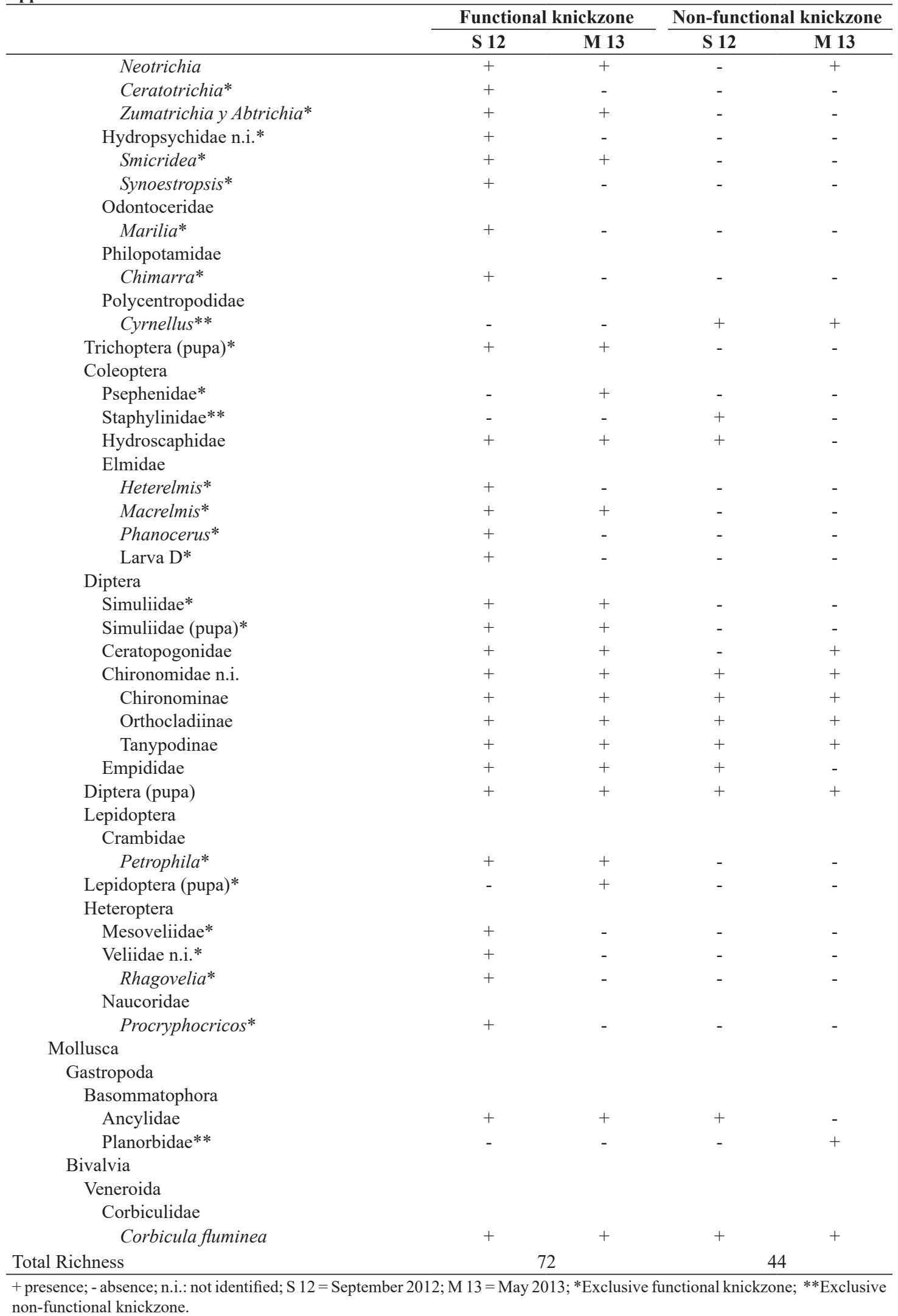

